
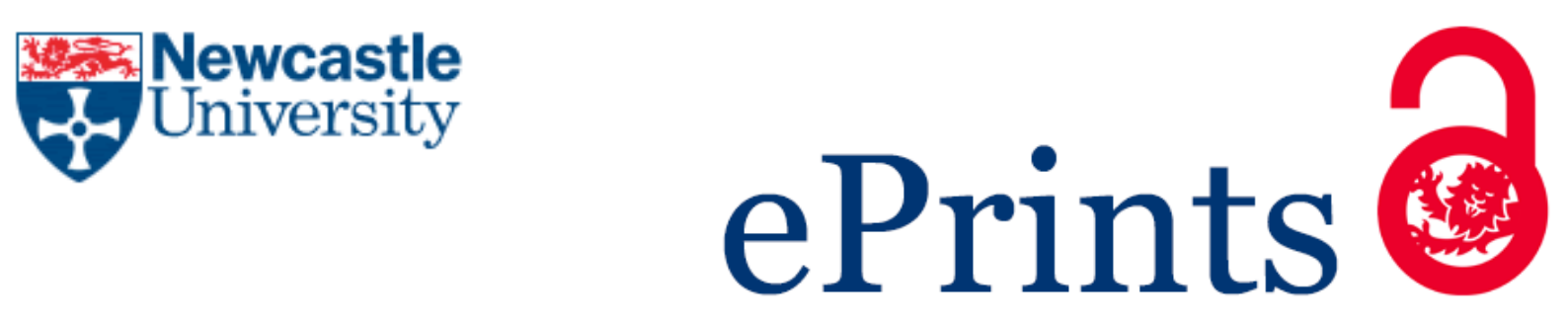

Blut M, Evanschitzky H, Backhaus C, Rudd J, Marck M. (2015)

Securing business-to-business relationships: the impact of switching costs.

Industrial Marketing Management

DOI: 10.1016/j.indmarman.2015.05.010

\title{
Copyright:
}

This is the author's version of a work accepted for publication. (C) 2015, Elsevier. Licensed under the Creative Commons Attribution-NonCommercial-NoDerivatives 4.0 International.

DOI link to article:

http://dx.doi.org/10.1016/j.indmarman.2015.05.010

Date deposited:

$27 / 04 / 2015$

Embargo release date:

23 May 2017

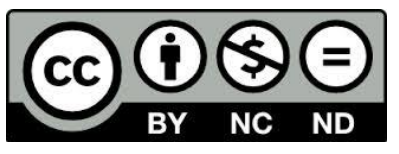

This work is licensed under a

Creative Commons Attribution-NonCommercial-NoDerivatives 4.0 International licence 


\title{
SECURING BUSINESS-TO-BUSINESS RELATIONSHIPS: THE IMPACT OF SWITCHING COSTS
}

\author{
Markus Blut \\ Professor of Marketing \\ Newcastle University Business School \\ 5 Barrack Road, NE1 4SE Newcastle upon Tyne, UK \\ +44 (0) 1912081707 (phone) \\ +44(0) 1912081741 (fax) \\ markus.blut@newcastle.ac.uk \\ Heiner Evanschitzky* \\ Professor of Marketing \\ Aston Business School \\ Marketing Group \\ Aston Triangle \\ Birmingham, B4 7ET, UK \\ Christof Backhaus \\ Professor of Marketing \\ Newcastle University Business School \\ 5 Barrack Road \\ NE1 4SE Newcastle upon Tyne, UK \\ John Rudd \\ Professor of Marketing \\ Aston Business School \\ Marketing Group \\ Aston Triangle \\ Birmingham, B4 7ET, UK \\ Michael Marck \\ Lecturer in Marketing \\ Department of Marketing \\ University of Strathclyde \\ 173 Cathedral Street \\ G4 0RQ Glasgow, UK
}

*Corresponding author

Paper submitted to Industrial Marketing Management - GMC 2014 Special Joint Issue 


\section{SECURING BUSINESS-TO-BUSINESS RELATIONSHIPS: THE IMPACT OF SWITCHING COSTS}

While the relationship marketing literature acknowledges the importance of switching costs for increasing customer retention, little is known about its relevance in industrial markets. In particular, it is unclear whether switching costs, and associated dimensions, impact on behavioral outcomes of buyer-seller relationships in business-to-business (B2B) markets. In order to contribute to theory development in this important area, our research first explores the dimensions of switching costs for the B2B domain and also tests the relative impact of these dimensions on business customers' actual purchase behavior. Results suggest that switching costs in B2B settings are a multi-faceted construct, including (i) procedural, (ii) financial, and (iii) relational switching costs. Moreover, we find relational switching costs to be most important for securing B2B buyer-seller relationships since they impact a customer's (a) share-of-wallet, (b) cross-buying behavior, and (c) actual switching behavior. While procedural switching costs only influence share-of-wallet, financial switching costs solely impact customer's cross-buying behavior. These findings contribute to a better understanding on how to secure B2B buyer-seller relationships.

Key words: Buyer-seller relationships; switching costs; purchase behavior; customer satisfaction; mixed-method approach 
Investigating predictors of customer repurchase behavior is at the core of research in the field of business-to-business (B2B) relationship marketing. While established drivers such as customer perceived value, customer satisfaction, and trust have received considerable attention in the industrial marketing literature, surprisingly little is known about the relevance of switching costs (Anderson \& Mittal, 2000; Dall'Olmo Riley \& de Chernatony, 2000; Payne \& Hold, 2001; Szymanski \& Henard, 2001; Yanamandram \& White, 2006).

Switching costs are defined as the customer's perception of the magnitude of additional costs required to conclude the current relationship, and secure an alternative supplier (Blut et al. 2015; Jackson, 1985; Ping, 1993; Porter, 1980; Yanamandram \& White, 2006). ${ }^{1}$ Unsurprisingly, it seems, management practice and tactics are often aimed at increasing switching costs through introducing loyalty schemes or offering unique customer solutions. Recent examples in the B2B context include General Electric's 2014 'Innovation at work' television campaign or Lufthansa's PartnerPlusBenefit loyalty program.

Managers making investment in switching cost-increasing measures assume that these activities will strengthen customer relationships. Due to higher specific investments and a greater complexity of the purchasing process in the $\mathrm{B} 2 \mathrm{~B}$ context, it is perhaps reasonable to expect that switching costs are of even greater importance in interorganizational settings than they are in business-to-consumer (B2C) markets.

Interestingly however, a recent meta-study on the effectiveness of switching costs across different contexts indicates that perceived switching costs generally show a weak average correlation with switching intention $(r=-.090, p<.05)$. Even more surprisingly, this study points out that switching costs are more effective in consumer markets than they are in industrial

\footnotetext{
${ }^{1}$ Usually, switching costs studies examine the perceived costs of switching instead of real costs (although this examination would be interesting) (Jones et al. 2000). Therefore, whenever we use the term switching costs in the manuscript, we refer to the costs perceived by the customer.
} 
markets $\left(r_{\mathrm{B} 2 \mathrm{C}}=-.113\right.$ versus $\left.r_{\mathrm{B} 2 \mathrm{~B}}=-.065\right)($ Pick \& Eisend, 2013). The low association between switching costs and switching intention for industrial clients may be interpreted in the light of two characteristics that apply to the majority of research in the B2B switching costs literature.

First, switching costs are usually conceptualized as a one-dimensional construct (e.g., Geiger et al., 2012; Sengupta, Krapfel, \& Pusateri, 1997). With regard to the switching costs literature however, it can be assumed that switching costs represent a multi-dimensional construct consisting of several sub-dimensions or facets (e.g., Burnham, Frels, \& Mahajan, 2003; Jones, Mothersbaugh, \& Beatty, 2002). It may be that some switching costs were of greater relevance for securing B2B relationships than others.

Second, most research investigating outcomes of switching costs has relied on self-reported purchase behavior (Blut et al. 2015). Thereby, given that self-reported measures of purchase behavior usually do not perfectly correspond to actual purchase behavior, switching costs may show differential effects for actual behavior compared to self-reported purchase intentions (Blut et al. 2007, 2015; Chebat et al., 2011; Wirtz et al. 2014; Woisetschläger, Lentz, \& Evanschitzky 2011).

Summing up these arguments, it is unclear whether the meta-analytic finding of a rather weak association between switching costs and switching intention in B2B markets truly reflects business reality or is merely a result of methodological and conceptual shortcomings of the metaanalyzed studies. Against this background, our research intends to deepen understanding of the relative impact of switching cost dimensions on customer behavior in industrial markets by:

(a) Conceptually developing and empirically exploring the dimensional structure of switching costs, as perceived by industrial customers. 
(b) Examining the precise impact of switching cost dimensions, on the purchase behavior of industrial customers.

Given the lack of consensus on the dimensionality of switching costs in B2B markets (Barroso \& Picón, 2012), our research employs a mixed-method design, and is organized as follows. Study 1 explores the dimensionality of switching costs in the B2B domain, drawing on input gained from 38 in-depth interviews with B2B customers of staffing agencies. Based on the identified dimensions, and using a sample of customers of a European supplier of chemical products and related services, Study 2 assesses the relative impact of switching costs on actual purchase behavior. Finally, we discuss our findings on the relative impact of switching costs from both managerial and academic perspectives.

\section{STUDY 1: CONCEPTUALIZATION OF SWITCHING COSTS}

\section{Study Purpose and Method}

In order to develop our understanding of the dimensions of switching costs, we conducted a qualitative study, conducting in-depth interviews with 38 staffing agency customers who had recently switched service providers. Interviewing those that have switched service providers is crucial, since we want to understand the dimensions of the switching costs construct. To ensure reliable recall by respondents, we followed a procedure suggested by Keaveney (1995), verifying that termination of the customer relationship had occurred within a six month time period prior to the interviews. We then identified within each company those responsible for the switching decision. Those that were interviewed held titles such as vice president, human resources manager, or operations manager; indicating that in B2B businesses a broad variety of functions 
are involved in switching matters. ${ }^{2}$ On average, respondents had about eight years of industry experience, indicating considerable expertise in their field.

Interviews were conducted by means of open-ended surveys. On average, interviews lasted an hour and half, resulting in a total of approximately 60 interview hours. All interviews were recorded, and the transcripts were assessed with the aid of the QSR NVivo software. One designated author conducted all interviews and transcriptions, in order to avoid problems such as variation in recording or inter-interviewer bias. Data coding was accomplished iteratively by means of an inductive categorization method (Spiggle, 1994; Strauss \& Corbin, 1990). Identification and categorization of relevant factors related to the switching decision was processed by two of the authors.

\section{Results}

Responses from the interviews allowed us to identify factors that made it difficult to switch from the current provider. Our results indicate that customers differentiate between eight facets of switching costs, which can be assigned to three higher-order dimensions (Table 1). With regard to the latter aspect, we found that switching costs in industrial markets can be distinguished into procedural, financial, and relational switching costs according to the conceptualization of Burnham, Frels, \& Mahajan (2003). ${ }^{3}$

\section{Table 1 about here}

First, procedural switching costs involve the expenditure of time and effort in locating, adopting, and using a new brand/provider as well as the uncertainty associated with this process.

\footnotetext{
${ }^{2}$ Please note that we did not find differences across the diverse participants in our qualitative interviews.

${ }^{3}$ A comprehensive assessment of this conceptualization is provided by Blut et al. (2015).
} 
In our interviews, we found that the participants referred to the following costs, and relate them to the process of switching to alternative suppliers: uncertainty costs $(n=14)$, pre-switching search and evaluation costs $(n=24)$, post-switching behavioral and cognitive costs $(n=15)$, and setup costs $(\mathrm{n}=17)$. Respondents typically associated the process of switching providers with levels of uncertainty and risk, and the potential for negative outcomes. Respondents noted that switching also requires them, as customers of a new company, to acquire skills and know-how in order to effectively use new products or services. Moreover, they perceived switching to be difficult and costly, particularly because of the burdensome measures required to gather necessary information. Finally, switching necessitates some time and effort in order to set up a new business relationship.

Second, financial switching costs involve the loss of financially quantifiable resources, including monetary losses (e.g. fees to break contract, initiation fees to adopt a new brand or provider) and lost benefits (e.g. loss of reward points, preferred access, or special status). Respondents mentioned financial switching costs as a significant concern in the decision to change provider. These costs include the loss of specific privileges and benefits, or lost performance costs $(n=24)$ and sunk costs $(n=19)$. Our interviews revealed that the loss of industry expertise when switching to an alternative service provider is an important switching cost (Goff et al., 1997). Respondents stated that they rely on a service provider's expertise to provide individualized service solutions, which saves on their operating costs. Moreover, these clients had made specific investments that would be lost when switching to a new provider.

Third, relational switching costs involve the loss of identification and emotional bonds with both the brand/provider and any employees with who the customer interacts. In our interviews, the participants argued that not only do impersonal (i.e. brand) relationships $(n=9)$ prevent them 
from switching to alternative suppliers, but personal relationships $(n=15)$ do as well. They found it difficult to switch because that meant breaking bonds.

Comparing the explored dimensions of the switching costs construct in our research setting, with a recent conceptualization suggested by Barroso \& Picón (2012) in the insurance industry for professional clients, we make the following observations: First, our study identified three dimensions of switching costs (procedural, financial, and relational) consisting of eight facets. Barroso \& Picón (2012), who recently examined one of the most comprehensive conceptualizations of switching costs in an industrial context, tested six dimensions of switching costs and combined them to an overall switching costs measure. In our conceptualization, we observe that participants of the in-depth interviews explicitly link the eight facets to three higher order switching cost dimensions. Hence, it appears that the main motivation for customers not to switch are either related to the process of switching (procedural switching costs), to financial losses (financial switching costs), or the breaking of relationships (relational switching costs).

Second, we observe that, similar to the study of Barroso \& Picón (2012), the participants in our study mention that the following costs hinder them from switching: uncertainty costs, preswitching search and evaluation costs, setup costs, lost performance costs, and personal relationships loss costs. Therefore, one can assume that these costs apply in a large number of industrial markets, and have a great potential to impact customer purchase behavior across industries.

Third, we identify some facets that were not examined by Barroso \& Picón (2012), and these are post-switching behavioral and cognitive costs, sunk costs, and brand relationship loss costs.

Based on this, and given our intention to fully explore the switching cost construct, we chose the chemical industry as the empirical setting of our main study (Study 2). Unlike the insurance 
service industry, specific investments are likely to be significant in the chemical industry due to the investments firms make into machines and equipment. Similarly, loss of brand relationship costs might play a more important role in the chemical industry, since personal selling and sales management approaches are utilized by the majority of companies. As revealed from the qualitative interviews, the comprehensive conceptualization of switching costs, comprising eight facets assigned to three dimensions, is used in our second study to uncover the relative impact these switching costs have on customer behavior.

\section{STUDY 2: THE RELATIVE IMPACT OF SWITCHING COSTS}

\section{Study Purpose}

In Study 2, we empirically test the impact of the different switching cost facets on actual customer purchase behavior. To avoid problems with common method bias, we investigate actual behaviors as dependent variables. Therefore, our conceptual model links the identified dimensions of switching costs (procedural, financial, relational) with four aspects of purchase behavior, i.e. customer switching behavior, share of wallet, and cross-buying behavior across both the firm's product and service categories. We assume each dimension of switching costs to impact the four behavioral outcome dimensions.

In addition to switching costs, we also include customer satisfaction in our conceptual model (Figure 1). We do so for two reasons: First, we want to control for the impact of customer satisfaction, since the loyalty literature suggests that satisfaction is a primary determinant of customer repurchase behavior, and several meta-analyses provide empirical evidence of its importance (Szymanski \& Henard, 2001; Palmatier et al., 2006). By doing so, we ensure that the observed purchase behavior is caused by the perceived switching costs and not by customer 
satisfaction instead. ${ }^{4}$ Second, the switching costs literature suggests switching costs to be an alternative strategy to bind customers to the firm (Jones et al., 2000). By simultaneously including customer satisfaction in our model, we can compare the relative effect of switching costs with customer satisfaction on the core outcomes.

\section{Figure 1 about here}

\section{Hypotheses}

While the relationship between switching costs and purchase intentions has received considerable attention in the literature (Blut et al. 2015; Pick \& Eisend, 2013), less is known about the impact of switching costs on actual purchase behavior in a B2B context. Prior research, testing the influence of switching costs on repurchase intentions, justified the impact of switching costs using a cost-benefit rationale (Jones et al., 2000). The higher the perceived costs of switching, the less likely the customer is to switch providers. For example, the customer would have to dissolve the relationship with the brand, the frontline employee, or lose financial benefits. In our study, we assume switching costs to be a multifaceted construct consisting of (non-)monetary costs associated with changing the provider (e.g. procedural switching costs) and (non-)monetary benefits that would be lost upon switching (e.g. relational and financial switching costs). Hence, these specific costs are likely to tie organizations to a specific provider (Jones et al., 2000). We therefore hypothesize:

\footnotetext{
${ }^{4}$ We also ran several analyses in which we controlled for the number of individuals being involved in purchase decisions, the existence of a contractual delivery agreement, and the length of the relationship with the current supplier. None of these control variables has impacted the four outcomes included in the conceptual model. In addition, we ran a few models including attractiveness of alternatives (as a measure of opportunity costs), but this variable did not show a significant effect.
} 
H1 (a) Procedural switching costs, (b) financial switching costs, and (c) relational switching costs have a negative effect on the customer's switching behavior.

The loyalty literature further differentiates between customer's actual switching behavior and the share of wallet as measures for customer purchase behavior. Share of wallet is a measure of how customers divide their purchases across competing suppliers (Evanschitzky et al., 2012). We define it as the percentage of the value of purchases from a supplier, to the total value of purchases from all other suppliers. While the customer's switching behavior variable measures whether a customer makes any purchase at all from a certain supplier, share of wallet indicates the extent of spending based on the customer's available budget. One customer could, for instance, purchase only the absolutely necessary products from one supplier (and all other related products form a different supplier). A switching behavior variable differentiating only between purchase and non-purchase would classify this customer as very loyal, whereas a share of wallet measure would indicate a low level of loyalty for this type of customer. Applying the costbenefit rationale from above, switching costs also impact the customer's share-of-wallet. Hence,

$\mathbf{H}_{2}$ (a) Procedural switching costs, (b) financial switching costs, and (c) relational switching costs have a positive effect on the customer's share of wallet.

In addition to the impact of switching costs on customer's switching behavior and share of wallet, we also examine whether switching costs have the potential to impact cross-buying behavior. Cross-buying refers to the degree to which customers purchase products or services from a set of related or unrelated categories of a company (Reinartz \& Kumar, 2003). Previous studies on cross-buying used two main arguments to explain cross-buying behavior (Kumar et al. 
2008). Either it is argued that (a) lower costs are associated with the purchase of additional offerings from the same supplier, compared to purchases from alternative suppliers, or (b) it is argued with regard to the lower risks associated with purchasing from the current supplier.

Further to the risk argument of cross-buying, the literature explains that the associated risk of purchasing additional products accumulates more severely when customers purchase from different suppliers. A supplier being able to convince customers of its trustworthiness, is more likely to trigger cross-buying due to the lower risk of purchasing from this supplier. The literature on switching costs suggests that financial and relational switching costs are rooted in positive sources of constraint, indicating the goodwill of the supplier (Jones et al., 2007). A supplier with a strong brand and excellent customer relationships (relational switching costs) is more likely to develop a trustful relationship with its customers, and thus is more likely to make the customer buy from numerous product and service categories. Similarly, a provider offering specific (non-)monetary benefits (financial switching costs), displays strong customer orientation which is likely to result in a lower level of perceived risk in purchasing from additional product and services categories. With respect to procedural switching costs, one could argue that they complicate the switching process. When switching is more costly, cross-buying should be more likely since the costs of purchasing from alternative providers increases. Because cross-buying refers to the purchase of products and/or services from a set of categories of a company, we separately test the impact of switching costs on the cross-buying across products and services categories. Hence we state:

H3 (a) Procedural switching costs, (b) financial switching costs, and (c) relational switching costs have a positive effect on the customer's cross-buying behavior across the firm's product categories. 
H4 (a) Procedural switching costs, (b) financial switching costs, and (c) relational switching costs have a positive effect on the customer's cross-buying behavior across the firm's services categories.

\section{Method}

\section{Data Collection Procedure and Sample}

Our study is set in the highly competitive market for chemical products and solutions. The firm in Study 2 can be regarded as a typical solution provider in this market in terms of size and success. A list of all business customers was supplied to us by the managers of this firm, and a random sample of 1,000 was drawn from this, and subsequently contacted through a professional market research company. From this sample, we were able to conduct 214 telephone interviews for a response rate of $21.4 \%$. We could not match survey data with all transaction data for selected participants lowering the final sample to 184 . The selected sample is representative for the total population of business customers in terms of industry affiliation and average annual sales (Table 2). It is worth noting that chemical products and solutions are important for the core businesses of the companies we interviewed.

\section{Table 2 about here}

\section{Measures and Measurement Properties}

As dependent variables, we examine the customers' actual switching behavior, the share of wallet, as well as cross-buying products and services. Instead of asking the customer about their behavior, we were granted access to the recordings of the supplier. For each customer, we received an overview over the purchase history of the last 12 months, the product categories 
from which the customer has purchased during this time period, and information about whether the customer stopped ordering throughout the last year. ${ }^{5}$ The share of wallet variable is defined as the percentage of the value of purchases by a customer from a supplier to the total value of purchases from all other suppliers. For this measure, we combined transactional data and customer survey data, since the firm's data base does not include purchases from alternative suppliers. We used the total purchases of an individual company for one year, and divided it by the total purchases of this company within this product category from all providers. While the former is taken from the supplier's database, the latter was reported by the customer in the customer survey. The measure we used for our study is in line with conventional assessments of customer behavior by managers in this industry. We further measured cross-buying behavior as the degree to which customers purchase (1) products or (2) services from a set of categories of the company's assortment.

Conceptualization and items for measuring the latent constructs were developed by drawing on prior research, using multi-item 5-point Likert-type scales. For measurement of customer satisfaction we used a scale from Fornell et al., (1996). The measure captures a customer's overall satisfaction and expectancy conformation using two items (Alpha: $n$. a.; $\mathrm{CR}=.86 ; \mathrm{AVE}=$ .75). As we found switching costs to be a multi-dimensional construct, we searched for scales in the literature that cover most of our eight identified sub-dimensions. In particular, the switching cost measures from Jones et al. (2002) and Burnham et al. (2003) appeared to offer the best solution. These measures capture costs across a variety of dimensions such as:

\footnotetext{
${ }^{5}$ The survey was conducted after some customers have switched. Combining data about the customers past transactions with survey data is a common practice which has the advantage that it avoids common method bias.
} 
- Procedural switching costs (overall: Alpha $=.89 ; \mathrm{CR}=.88 ; \mathrm{AVE}=.66$ ), with its four sub-dimensions: uncertainty costs, pre-switching search and evaluation costs, postswitching behavioral and cognitive costs, and setup costs;

- Financial switching costs (overall: Alpha $=.86 ; \mathrm{CR}=.89 ; \mathrm{AVE}=.68$ ), with its two subdimensions of sunk costs and lost performance costs;

- Relational switching costs (overall: Alpha $=.72 ; \mathrm{CR}=.83 ; \mathrm{AVE}=.61$ ), consisting of brand relationship loss costs and personal relationship loss costs.

Measurement reliability was examined through confirmatory factor analysis and the calculation of Cronbach's alpha coefficients. Tables 3 and 4 provide an overview of the psychometric properties of the measures used in this study.

\section{Tables 3-4 about here}

It can be noted that the coefficient alpha is larger than .7 for all examined constructs, a threshold generally proposed in the literature (Nunnally, 1978). Also, composite reliabilities (CR) are larger than .6 for all constructs (Bagozzi \& Yi, 1988). Discriminant validity between the three switching cost dimensions and the two antecedents of customer behavior was assessed using the criterion proposed by Fornell \& Larcker (1981). The criterion was met, as the average variance extracted (AVE) by each construct exceeded the squared correlations between all pairs of constructs. Therefore, reliability and validity of the constructs in this study are within acceptable boundaries.

\section{Results}


Before testing the hypotheses, we compared our findings with the results obtained in the meta-study reported by Pick \& Eisend (2013) to test whether our basic assumption that switching costs impact customer behavior in industrial markets holds. Therefore, we have contrasted the correlations reported by the meta-study with the correlations in our data set (Table 5).

\section{Table 5 about here}

Results indicate that the correlations in our study were significantly stronger for each of the switching costs dimensions and each outcome variable. To empirically test the relative impact of each switching costs dimension against each other, we used regression analysis. An additional benefit of regression analysis is that it allows analyzing the marginal effects of the independent variables on purchase behavior (i.e. the impact of a one-unit increase in satisfaction on share of wallet). ${ }^{6}$ We created composite scales for the three switching cost dimensions by calculating the means of all items, measuring each type of switching costs (Greene, 2007; Zellner \& Theil, 1962). We also created scale means for customer satisfaction. This process allowed us to create four independent variables for our regression analyses. In addition, we included four variables to measure actual purchase behavior. Multicollinearity within the regression model was assessed by investigating the variance inflation factors (VIF). Results show VIFs between 1.077 and 1.720, well below the thresholds proposed in the literature (Hair et al., 2006).

\footnotetext{
${ }^{6} \mathrm{We}$ also employed structural equation modelling using LISREL to test our hypotheses. This method has the advantage that it allows modelling relationships between independent constructs. All effects being significant in our regression analysis were also significant in LISREL. The main difference between both methods is that the relationship between procedural switching costs and share of wallet is significant on a .1-level in LISREL and on a .05-level using regression.
} 
Results of hypotheses testing indicate that several types of switching costs show a strong relationship with actual purchase behavior. Further, different types of switching costs impact the four outcomes measures differently (Table 6).

\section{Table 6 about here}

More precisely, we find that relational switching costs were positively related to all four purchase behavior measures. Particularly, we find relational switching costs to be associated with customer's switching behavior $(\beta=-.165, \mathrm{p}<.05)$, share of wallet $(\beta=.176, \mathrm{p}<.05)$, crossbuying across product categories $(\beta=.168, \mathrm{p}<.05)$, and cross-buying across services categories ( $\beta=.330, \mathrm{p}<.05)$. Therefore, all hypotheses related to relational switching costs, $\mathrm{H} 1 \mathrm{c}, \mathrm{H} 2 \mathrm{c}, \mathrm{H} 3 \mathrm{c}$, and $\mathrm{H} 4 \mathrm{c}$, were supported by these findings. With respect to procedural switching costs, we only find these costs to be related to share of wallet $(\beta=.141, \mathrm{p}<.05)$, but not to the remaining outcomes. Consequently, hypotheses $\mathrm{H} 2 \mathrm{a}$ is supported while $\mathrm{H} 1 \mathrm{a}, \mathrm{H} 3 \mathrm{a}$, and $\mathrm{H} 4 \mathrm{a}$ were not supported by our findings. Finally, we observe financial switching costs to be associated with the customers' cross-buying behavior across product categories $(\beta=.199, \mathrm{p}<.05)$, and their crossbuying across services categories $(\beta=.208, \mathrm{p}<.05)$, lending support for hypotheses H3b and $\mathrm{H} 4 \mathrm{~b}$, but not for hypotheses $\mathrm{H} 1 \mathrm{~b}$ and $\mathrm{H} 2 \mathrm{~b}$. We also observe that customer satisfaction in the chemical industry strongly impacts share of wallet $(\beta=.337, \mathrm{p}<.05)$. However, the remaining relationship marketing outcomes are primarily driven by one of the switching costs dimensions, and not by customer satisfaction. This result underlines the general importance of switching costs in industrial markets. With respect to the variance explained, we observe that customer satisfaction and switching costs together explain 8.5 percent of the variance of purchase behavior 
of customer switching behavior, 23.0 percent of share of wallet, 14.3 percent of cross-buying behavior across product categories, and 25.3 percent of cross-buying behavior across service categories. These $\mathrm{R}^{2}$-values are in line with results obtained by other studies that are based on behavioral data (e.g., Mittal \& Kamakura, 2001; Verhoef, Franses, \& Hoekstra, 2002).

Since the switching costs literature also discusses a two-dimensional typology of switching costs, we also test this alternative conceptualization differentiating between positive and negative switching costs (Blut et al. 2014; Jones et al. 2007; Nagengast et al. 2014). It is argued that procedural switching costs were rooted in negative sources of constraint, while financial and relational switching costs are discussed to be rooted in positive sources of constraint. The results differ from the previous analysis with respect to positive switching costs (= financial and relational switching costs), because they were found to impact all outcomes variables: switching behavior $(\beta=-.208, \mathrm{p}<.05)$, share of wallet $(\beta=.237, \mathrm{p}<.05)$, cross-buying behavior across product categories $(\beta=.326, \mathrm{p}<.05)$, and cross-buying across services categories $(\beta=.489, \mathrm{p}<$ .05). Since financial switching costs were insignificant regarding switching behavior and share of wallet in the previous analyses and only relational switching costs impact all outcome variables, we suggest employing the three- instead of the two-dimensional classification. Otherwise, managers would not be able to detect these differential effects and would develop false expectations regarding the establishment of financial switching costs.

\section{DISCUSSION}

Due to the inconclusive findings regarding the role of switching costs on customer purchase behavior in the literature, this research was driven by two primary motivations. First, with regard to the lack of consensus on the nature and facets of switching costs in B2B markets, we intended 
to conceptualize switching costs for B2B industries. Second, we attempted to assess the effectiveness of switching costs by examining the impact of switching costs on the industrial customer's actual purchase behavior.

\section{Implications for the Switching Costs Literature}

Extending recent research on the conceptualization of switching costs, results from the qualitative study suggest that switching costs in industrial markets represent a multi-dimensional construct consisting of eight facets (or sub-dimensions) which represent three (higher-order) dimensions. More specifically, we identified procedural switching costs (uncertainty costs, preswitching search and evaluation costs, post-switching behavioral and cognitive costs, setup costs), financial switching costs (lost performance costs, sunk costs), and relational aspects (brand relationships and personal relationships) as important and relevant dimensions of switching costs in B2B settings. Similar to Barroso \& Picón (2012), we find that uncertainty costs, pre-switching search and evaluation costs, setup costs, lost performance costs, and personal relationships loss costs represent switching costs have the potential to prevent a customer from switching. It seems that these switching costs matter in several industries due to their universal nature. Moreover, results from our interviews indicate that post-switching behavioral and cognitive costs, sunk costs, and brand relationship loss costs matter in the examined industries. Thus, we identify further switching costs sub-dimensions which go beyond the dimensions discussed by Barroso \& Picón (2012). It may be that staffing agency industry and chemical industry are more complex as compared to insurance industry, making post-switching behavioral and cognitive costs, sunk costs, and brand relationship loss costs gain importance.

With regard to the relative effect of switching costs on actual purchase behavior, results of the quantitative study show that the three dimensions of procedural, financial, and relational 
switching costs affect key relationship marketing outcomes to a different extent. Particularly, we find relational switching costs to be the most important type of switching cost for securing business-to-business relationships since it impacts share-of-wallet, cross-buying behavior, and the actual switching behavior. While procedural switching costs only influence share-of-wallet, financial switching costs only impact cross-buying behavior across a firm's product and services categories. These findings underscore the need to differentiate between the diverse dimensions of the switching costs construct. Additionally, these findings underline the attractiveness of switching costs as a retention strategy for many industrial markets. The latter result appears to be subtle, but it is nonetheless an important finding for switching costs research. While the metastudy from Pick \& Eisend (2013) questioned the relevance of switching costs, our study is able to show that at least some dimensions of the switching costs construct impact actual purchase behavior.

With respect to the differential effects of switching costs, this study deepens our understanding of the nature of the three switching cost dimensions. Financial and relational switching costs were found to influence cross-buying behavior of products and services. The literature argues that these two types of switching costs represent positive switching costs, expressing the goodwill of the supplier which in turns makes the customer buy from several product and services categories (Jones et al., 2007). Similarly, one can assume that these positive switching costs lead to other relationship marketing outcomes such as increased failure tolerance, positive word of mouth, and lower price sensitivity. Procedural switching costs refer to the expenditure of time and effort in locating, adopting, and using a new brand/provider as well as the uncertainty associated with this process. We found this type of switching cost to influence share of wallet. It seems that with greater complexity of searching for alternative suppliers and 
the associated costs, existing customers are more likely to spend the majority of their purchasing budget with one firm. While we do not find an effect for cross-buying behavior, at least procedural switching costs were found to matter for the share of wallet. Comparing the relative effect of switching costs with customer satisfaction, we find customer satisfaction to be the main driver of share of wallet, whereas relational switching costs is the dominant driver of crossbuying behavior and switching behavior, and financial switching costs is a major driver of crossbuying behavior.

\section{Managerial Implications}

For managers, our findings provide important guidance whether and how, to make use of switching costs in their industries.

First, our study indicates that managers being responsible for customer management should consider switching costs as major drivers of purchase behavior. More specifically, the dimensions of switching costs highlighted in this study allow managers to (a) benchmark their current level of switching costs, and (b) establish an agenda for change and for future developments in this area. Benchmarking may help to stimulate more thoughtful decisions regarding resource deployment in these important areas. Once these deliberations are complete, managers can make objective and informed strategic decisions on future actions relating to customer purchase behavior.

Second, with respect to the role of relational switching costs, managers could invest in human resource training. Salespeople need to be able to explain how, and where, products and services add value for customers, and they must be able to tailor the sales process to the respective customer. Moreover, part of the sales process should include recommendations on how the additional value created by the products and services offered can be embedded into the 
individual customer's systems and processes. If it is not salespeople who are responsible for the on-going product and service delivery, the appropriate training should be given to those who are responsible. Additionally, the results presented underscore the power of strong brands. Organizations that recognize the importance of investment in brands and other customer-related marketing initiatives will be more successful in retaining customers, and will reduce switching behavior.

Third, one example to increase procedural switching costs could be the provision of proprietary services, such as management support systems. As one interviewee stated, “We won't switch because it would cost too much to change our accounting systems." The more unique the current provider is perceived and the easier transactions were for the customer, the more time it consumes to identify alternative providers that were equally excellent and the more difficult it is to get used to the routines of the new provider. One senior manager indicated in our qualitative study, "Our switching costs would have to include the time and costs to re-train our staff (...); lost production time is very costly to us." Further actions to improve procedural switching costs are the offering of customized services, after-sales service contracts, consulting services, and more convenient ordering processes (e.g., Nagengast et al. 2014).

Finally, financial switching costs could be increased by offering special discounts for longterm business partners, by providing free extra services which create additional value for the customer, or by providing privileges (e.g., 24-h service, individual contact person) to the customer that might be lost when switching. These actions could either include creation of additional benefits (e.g., loss of reward points, preferred access, or special status) for existing 
customers or they could include establishment of monetary losses for customers when switching (e.g., fees to break contract, initiation fees to adopt a new brand or provider). ${ }^{7}$

\section{Limitations and Further Research}

As with all empirical studies, our study has some limitations. The following directions for further studies were derived from these limitations, as well as from the desire to gain further insight into the role of switching costs for securing industrial buyer-supplier relationships.

First, regarding our qualitative study, the interviews were conducted in a single, large metropolitan area in one country. There is potential for limited applicability of the findings to other geographical areas. Since literature on internal management indicates that the relevance of relationships differ across cultures, it might be that in collectivistic cultures, relational switching costs were of greater importance than in individualistic cultures. Similarly, one could assume that the effectiveness of financial switching costs is influenced by the long-term versus shortterm orientation of a culture.

Second, we analyzed in our quantitative study a particular firm from one industry and one country. To further generalize our findings, a cross-industry analysis should be conducted involving different countries and different industries in particular. Comparing our findings in the chemical products and services industry with Barroso \& Picón's (2012) findings from insurance, we were able to identify several switching costs that were of relevance in our context but not in the insurance industry. We suggest testing the generalizability of the identified dimension in additional industries such as capital goods industry (which is characterized by a greater product complexity and higher investments) or consulting industry (which involves a closer contact between a firm's employees and the customers).

\footnotetext{
${ }^{7}$ According to the suggestion of one anonymous reviewer, we have split the dataset according to the customer segment. We divided the dataset into two groups using the sales median. Comparing the correlations between all constructs in the high sales group with the correlations in the whole dataset, we find that the results are very similar.
} 
Third, further studies should examine the impact of switching costs in firms employing a buying center, since different roles in this center might influence the efficacy of switching costs. In our study we controlled for the number of individuals being involved in the purchase decisions and found that our results were not impacted by the number of individuals involved. Nonetheless, we only interviewed the final decision maker and the perception of switching costs might differ across the diverse roles.

Finally, we analyzed data from one particular point in time only and, thereby, we presume the absence of time-lags between a customer's perception of switching costs and their future behavior. Further research is needed to control for these effects by gathering longitudinal data.

\section{Conclusion}

To sum up, the contribution of this research is two-fold. We show that switching costs matter in industrial markets, since they impact actual purchase behavior. Also, it becomes clear that switching costs should be conceptualized as multi-dimensional construct with three higherorder switching cost dimensions (procedural, financial, and relational) and eight sub-dimensions. Thereby, we were able to show that relational switching costs are most important for securing business-to-business relationships, since they impact (a) share-of-wallet, (b) cross-buying behavior, and (c) actual switching behavior. While procedural switching costs only influence the share-of-wallet, financial switching costs only impact cross-buying. 


\section{REFERENCES}

Anderson, E. W., \& Mittal, V. (2000). Strengthening the Satisfaction-Profit Chain. Journal of Service Research, 3(2), 107-120.

Bagozzi, R. P., \& Yi, Y. (1988). On Evaluation of Structural Equation Models. Journal of the Academy of Marketing Science, 16(2), 74-94.

Barroso, C., \& Picón, A. (2012). Multi-dimensional analysis of perceived switching costs. Industrial Marketing Management, 41(3), 531-543.

Blut, M., Beatty, S., Evanschitzky, H., \& Brock, C. (2014). The Impact of Service Characteristics on the Switching Costs-Customer Loyalty Link. Journal of Retailing, 90 (2), 275-290.

Blut, M., Evanschitzky, H., Vogel, V., \& Ahlert, D. (2007). Switching barriers in the four-stage loyalty model. Advances in Consumer Research, 34, 726-734.

Blut M., Frennea, C.M., Mittal, V., \& Mothersbaugh D. L. (2015). How Procedural, Financial, and Relational Switching Costs Affect Customer Satisfaction, Repurchase Intentions, and Repurchase Behavior: A Meta-Analysis. International Journal of Research in Marketing, doi:10.1016/j.ijresmar.2015.01.001.

Burnham, T. A., Frels, J. K., \& Mahajan, V. (2003). Consumer Switching Costs: A Typology, Antecedents, and Consequences. Journal of the Academy of Marketing Science, 31(2), $109-127$.

Chebat, J. C., Davidow, M., \& Borges, A. (2011). More on the role of switching costs in service markets: a research note. Journal of Business Research, 64(8), 823-829.

Dall'Olmo Riley, F., \& de Chernatony, L. (2000). The Service Brand as Relationships Builder. British Journal of Management, 11(2), 137-150. 
Evanschitzky, H., Ramaseshan, B., Woisetschläger, D. M., Richelsen, V., Blut, M., \& Backhaus, C. (2012). Consequences of customer loyalty to the loyalty program and to the company. Journal of the Academy of Marketing Science, 40(5), 625-638.

Fornell, C., Johnson, M. D., Anderson, E. W., Cha, J., \& Bryant, B. E. (1996). The American Customer Satisfaction Index: Nature, Purpose, and Findings. Journal of Marketing, 60(4), $70-87$.

Fornell, C,. \& Larcker, D. F. (1981). Evaluating Structural Equation Models with Unobservable Variables and Measurement Error. Journal of Marketing Research, 18(1), 39-50.

Geiger, I., Durand, A., Saab, S., Kleinaltenkamp, M., Baxter, R., \& Lee, Y. (2012). The bonding effects of relationship value and switching costs in industrial buyer-seller relationships: An investigation into role differences. Industrial Marketing Management, 41(1), 82-93.

Goff, B. G., Boles, J. S., Bellenger, D. N., \& Stojack, C. (1997). The Influence of Salesperson Selling Behaviors on Customer Satisfaction with Products. Journal of Retailing, 73(2), $171-184$.

Greene, W. H. (2007). Econometric Analysis, $6^{\text {th }}$ ed. Upper Saddle River, NJ: Pearson.

Grewal, D. \& Levy, M. (2009). Marketing. New York, NY: McGraw Hill.

Hair, J. F., Black, B., Babin, B., Anderson, R. E., \& Tatham, R. L. (2006). Multivariate Data Analysis, 6th ed. Upper Saddle River, NJ: Prentice

Jackson, B. B. (1985). Build Customer Relationships That Last: How Close Can Industrial Markets Get to Their Customers - And For How Long?. Harvard Business Review, 63(6), $120-128$.

Jones, M. A., Mothersbaugh, D. L., \& Beatty, S. E. (2000). Switching Barriers and Repurchase Intentions in Services. Journal of Retailing, 76(2), 259-274. 
Jones, M. A., Mothersbaugh, D. L., \& Beatty, S. E. (2002). Why Customers Stay: Measuring the Underlying Dimensions of Services Switching Costs and Managing Their Differential Strategic Outcomes. Journal of Business Research, 55(6), 441-550.

Jones, M. A., Reynolds, K. E., Mothersbaugh, D. L., \& Beatty, S. E. (2007). The Positive and Negative Effects of Switching Costs on Relational Outcomes. Journal of Service Research, $9(4), 335-355$.

Keaveney, S. M. (1995). Customer Switching Behavior in Service Industries: An Exploratory Study. Journal of Marketing, 59(2), 71-82.

Mittal, V., \& Kamakura, W. A. (2001). Satisfaction, repurchase intent, and repurchase behavior: investigating the moderating effect of customer characteristics. Journal of Marketing Research, 38(1), 131-142.

Nagengast, L., Evanschitzky, H., Blut, M., \& Rudolph, T. (2014). New Insights in the Moderating Effect of Switching Costs on the Satisfaction-Loyalty Link. Journal of Retailing, 90(3), 408-427.

Nunnally, J. C. (1978). Psychometric Theory. New York, NY: McGraw-Hill.

Palmatier, R. W., Dant, R. P., Grewal, D., \& Evans, K. R. (2006). Factors Influencing the Effectiveness of Relationship Marketing: A Meta-Analysis. Journal of Marketing, 70(4), 136153.

Payne, A. \&, Holt, S. (2001). Diagnosing Customer Value: Integrating the Value Process and Relationship Marketing. British Journal of Management, 12(2), 159-182.

Pick, D., \& Eisend, M. (2013). Buyers' perceived switching costs and switching: a meta-analytic assessment of their antecedents. Journal of the Academy of Marketing Science, (forthcoming). 
Ping, R. A. (1993). The Effects of Satisfaction and Structural Constraints on Retailer Exiting, Voice, Loyalty, Opportunism, and Neglect. Journal of Retailing, 69(3), 320-352.

Porter, M. E. (1980). Competitive Strategy: Technologies for Analyzing Industries and Competitors. New York, NY: Free Press.

Reinartz, W. J., \& Kumar, V. (2003). The impact of customer relationship characteristics on profitable lifetime duration. Journal of Marketing, 67(1), 77-99.

Sengupta, S., Krapfel, R. E., \& Pusateri, M. A. (1997). Switching Costs in Key Account Relationships'. Journal of Personal Selling and Sales Management, 17(4), 9-16.

Spiggle, S. (1994). Analysis and Interpretation of Qualitative Data in Consumer Research. Journal of Consumer Research, 21(4), 491-503.

Strauss, A., \& Corbin, J. (1990). Basics of Qualitative Research: Grounded Theory Procedures and Techniques. Beverly Hills, CA: Sage Publications.

Szymanski, D. M., \& Henard, D. H. (2001). Customer Satisfaction: A Meta-Analysis of the Empirical Evidence. Journal of the Academy of Marketing Science, 29(1), 16-36.

Verhoef, P. C., Franses, P. H., \& Hoekstra, J. C. (2002). The effect of relational constructs on customer referrals and number of services purchased from a multiservice provider: does age of relationship matter? Journal of the Academy of Marketing Science, 30(3), 202-216.

Webster, Jr., F. E. (1978). Management Science in Industrial Marketing. Journal of Marketing, 42(1), 1-27.

Woisetschläger, D. M., Lentz, P., \& Evanschitzky, H. (2011). How habits, social ties, and economic switching barriers affect customer loyalty in contractual service settings. Journal of Business Research, 64(8), 800-808. 
Wirtz, J., Xiao, P., Chiang, J. \& Malhotra, N. (2014). Contrasting the Drivers of Switching Intent and Switching Behavior in Contractual Service Settings. Journal of Retailing, forthcoming, DOI: 10.1016/j.jretai.2014.07.002

Yanamandram, V., \& White, L. (2006). Switching Barriers in Business-to-business Services: A Qualitative Study. International Journal of Service Industry Management, 17 (2), 158-192.

Zellner, A. \& Theil, H. (1962). Three-Stage Least Squares: Simultaneous Estimation of Simultaneous Equations. Econometrica, 30(1), 54-78. 
FIGURE 1

CONCEPTUAL MODEL AND HYPOTHESES

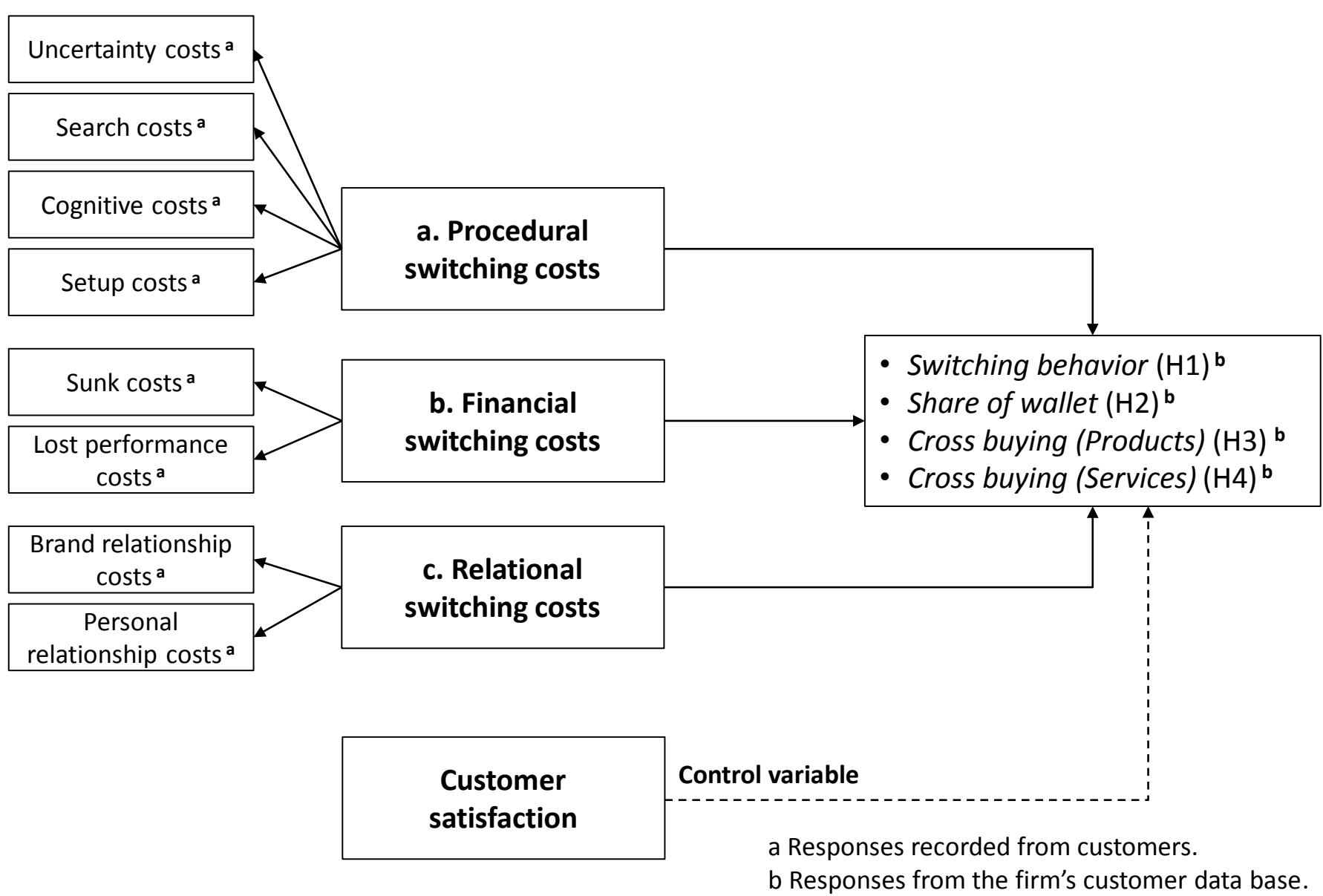


TABLE 1

DIMENSIONS OF SWITCHING COSTS IN B2B INDUSTRIES

\begin{tabular}{|c|c|c|c|}
\hline Frequency & $\begin{array}{l}\text { Dimension } \\
\text { (sub-dimension/facet) }\end{array}$ & Description & Source \\
\hline 14 & $\begin{array}{l}\text { PROCEDURAL SWITCHING COSTS } \\
\text { Uncertainty costs }\end{array}$ & $\begin{array}{l}\text { Perceptions of the likelihood of lower performance } \\
\text { when switching }\end{array}$ & Jones et al. (2002) \\
\hline 24 & Pre-switching search and evaluation costs & $\begin{array}{l}\text { Perceptions of the time and effort of gathering and } \\
\text { evaluating information prior to switching }\end{array}$ & Jones et al. (2002) \\
\hline 15 & Post-switching behavioral and cognitive costs & $\begin{array}{l}\text { Perceptions of the time and effort of learning a new } \\
\text { service routine subsequent to switching }\end{array}$ & Jones et al. (2002) \\
\hline 17 & Setup costs & $\begin{array}{l}\text { Perceptions of the time, effort, and expense of } \\
\text { relaying needs and information to provider } \\
\text { subsequent to switching }\end{array}$ & \\
\hline 19 & $\begin{array}{l}\text { FINANCIAL SWITCHING COSTS } \\
\text { Sunk costs }\end{array}$ & $\begin{array}{l}\text { Perceptions of investments and costs already incurred } \\
\text { in establishing and maintaining relationship }\end{array}$ & Jones et al. (2002) \\
\hline 24 & Lost performance costs & $\begin{array}{l}\text { Perceptions of the benefits and privileges lost by } \\
\text { switching }\end{array}$ & Jones et al. (2002) \\
\hline 9 & $\begin{array}{l}\text { RELATIONAL SWITCHING COSTS } \\
\text { Brand relationship loss costs }\end{array}$ & $\begin{array}{l}\text { Perceptions of losses with breaking the bonds of } \\
\text { identification that have been formed with the brand } \\
\text { or company with which a customer has associated }\end{array}$ & $\begin{array}{l}\text { Burnham et al. } \\
\text { (2003) }\end{array}$ \\
\hline 15 & Personal relationship loss costs & $\begin{array}{l}\text { Perceptions of losses associated with breaking the } \\
\text { bonds of identification that have been formed with } \\
\text { the people with whom the customer interacts }\end{array}$ & $\begin{array}{l}\text { Burnham et al. } \\
\text { (2003) }\end{array}$ \\
\hline
\end{tabular}


TABLE 2

SAMPLE COMPOSITION

\begin{tabular}{lc}
\hline & $\begin{array}{c}\text { Distribution of } \\
\text { sampled customers by } \\
\text { customer class/industry }\end{array}$ \\
\hline Industry & $\mathbf{1 5 \%}$ \\
Customers from Industry 1 & $3 \%$ \\
Customer Class A & $16 \%$ \\
Customer Class B & $27 \%$ \\
Customer Class D & $24 \%$ \\
Customer Class E & $30 \%$ \\
Customers from Industry 2 & $\mathbf{2 9 \%}$ \\
Customer Class A & $1 \%$ \\
Customer Class B & $3 \%$ \\
Customer Class C & $10 \%$ \\
Customer Class D & $21 \%$ \\
Customer Class E & $65 \%$ \\
Customers from Industry 3 & $\mathbf{2 5 \%}$ \\
Customer Class A & $0 \%$ \\
Customer Class B & $6 \%$ \\
Customer Class C & $16 \%$ \\
Customer Class D & $27 \%$ \\
Customer Class E & $50 \%$ \\
Customers from Industry 4 & $\mathbf{1 8 \%}$ \\
Customer Class A & $1 \%$ \\
Customer Class B & $2 \%$ \\
Customer Class C & $9 \%$ \\
Customer Class D & $17 \%$ \\
Customer Class E & $71 \%$ \\
Customers from Industry 5 & $\mathbf{1 3 \%}$ \\
Customer Class A & $1 \%$ \\
Customer Class B & $7 \%$ \\
Customer Class C & $22 \%$ \\
Customer Class D & $30 \%$ \\
Customer Class E & $41 \%$ \\
\hline & \\
&
\end{tabular}


TABLE 3

RELIABILITY AND VALIDITY OF THE CONSTRUCTS

\begin{tabular}{lccc}
\hline Scale/Item & Alpha & CR & AVE \\
\hline PROCEDURAL SWITCHING COSTS &. $\mathbf{8 9}$ & $\mathbf{. 8 8}$ & $\mathbf{. 6 6}$ \\
Uncertainty Costs (Jones et al. 2002) & .91 & .90 & .76
\end{tabular}

I am not sure what the level of service would be if I switched to a new provider.

If I were to change providers, the service I might receive at the new place could be worse than the service I now receive.

The service from another provider could be worse that the service I now receive.

$\begin{array}{llll}\text { Pre-switching Search and Evaluation Costs (Jones et al. 2002) } & \text { n.a. } & .85 & .65\end{array}$

It would take a lot of time and effort to locate a new provider.

If we changed provider, we would not have to search very much to find a new one.

Post-switching Behavioral and Cognitive Costs (Jones et al. 2002)

$\begin{array}{lll}.86 & .89 & .68\end{array}$

If I were to switch provider, I would have to learn how things work at a new one.

I would be unfamiliar with the policies of a new provider.

If I changed provider, I would have to learn how the "system works," at a new one.

Setup Costs (Jones et al. 2002)

$\begin{array}{lll}.95 & .84 & .73\end{array}$

If I changed provider, it would take a lot of time and effort on my part to explain to the new provider what I like and what I want.

If I changed provider, I would have to explain things to my new provider.

If we stopped purchasing from my current provider, we have to search a lot for a new one.

FINANCIAL SWITCHING COSTS

Sunk Costs (Jones et al. 2002)

$\begin{array}{lll}\mathbf{. 8 6} & \mathbf{. 8 9} & \mathbf{. 6 8} \\ .84 & .93 & .76\end{array}$

A lot of energy, time, and effort have gone into building and maintaining the relationship

with this provider.

Overall, we have invested a lot in the relationship with this provider.

We have spent a lot of time and money at this provider.

We have not invested much in the relationship with this provider.

Lost Performance Costs (Jones et al. 2002)

$.85 \quad .93 \quad .76$

This provider provides me with particular privileges I would not receive elsewhere.

By continuing to use the same provider, I receive certain benefits that I would not receive

if I switched to a new one.

There are certain benefits I would not retain if I were to switch provider.

I would lose preferential treatment if changed provider.

\begin{tabular}{llll}
\hline RELATIONAL SWITCHING COSTS & .72 & $\mathbf{. 8 3}$ & $\mathbf{. 6 1}$ \\
Brand Relationship Loss Costs (Burnham et al. 2003) & .70 & .77 & .54
\end{tabular}

I like my provider's the public image.

I support the provider as a firm.

I do not care about the brand/company name of the provider I use.

Personal Relationship Loss Costs (Jones et al. 2000)

$\begin{array}{lll}.71 & .85 & .59\end{array}$

I have developed a personal friendship with at least one employee at this provider.

I have somewhat of a personal relationship with at least one employee at this provider.

I am friends with at least one employee at this provider.

At least one employee is familiar with me personally.

CUSTOMER SATISFACTION

n.a. $\quad .86 \quad .75$

Overall, I am satisfied with this provider.

Based on all my experience with this provider, I am very satisfied

Note: All items are measured using 5-point Likert scales with the anchors 1 = fully disagree and 5 = fully agree; n.a.

$=$ not available. 
TABLE 4

CORRELATION MATRIX OF MODEL CONSTRUCTS

\begin{tabular}{|c|c|c|c|c|c|c|c|c|}
\hline Construct & 1. & 2. & 3. & 4. & 5. & 6. & 7. & 8. \\
\hline 1. Switching behavior & 1 & & & & & & & \\
\hline 2. Share of wallet & $-.431^{*}$ & 1 & & & & & & \\
\hline 3. Cross-buying (products) & $-.190^{*}$ & $.231^{*}$ & 1 & & & & & \\
\hline 4. Cross-buying (services) & $-.233^{*}$ & $.362^{*}$ & $.381^{*}$ & 1 & & & & \\
\hline 5. Procedural switching costs & $-.203^{*}$ & $.261^{*}$ & $.259^{*}$ & $.281^{*}$ & 1 & & & \\
\hline 6. Financial switching costs & $-.204^{*}$ & $.282^{*}$ & $.333^{*}$ & $.381^{*}$ & $.567^{*}$ & 1 & & \\
\hline 7. Relational switching costs & $-.232^{*}$ & $.311^{*}$ & $.282^{*}$ & $.451^{*}$ & $.252^{*}$ & $.399^{*}$ & 1 & \\
\hline 8. Satisfaction & -.106 & $.431^{*}$ & .116 & $.161^{*}$ & $.175^{*}$ & $.199^{*}$ & $.207^{*}$ & 1 \\
\hline
\end{tabular}

Note: Correlation coefficients being significant at least at the .05 -level are marked with an asterisk. 
TABLE 5

COMPARING THE CORRELATIONS OF THE PRESENT STUDY WITH THE META STUDY

\begin{tabular}{lccccc}
\hline & & \multicolumn{3}{c}{ Present Study } \\
\cline { 3 - 6 } Construct & $\begin{array}{c}\text { Meta-Study } \\
\text { (Pick \& Eisend, 2013) }\end{array}$ & Switching Behavior & $\begin{array}{c}\text { Share of } \\
\text { Wallet }\end{array}$ & $\begin{array}{c}\text { Cross-Buying } \\
\text { (Products) }\end{array}$ & $\begin{array}{c}\text { Cross-Buying } \\
\text { (Services) }\end{array}$ \\
\hline Procedural switching costs & -.065 & $-.203^{*}$ & $.261^{*}$ & $.259^{*}$ & $.281^{*}$ \\
Financial switching costs & -.065 & $-.204^{*}$ & $.282^{*}$ & $.333^{*}$ & $.381^{*}$ \\
Relational switching costs & -.065 & $-.232^{*}$ & $.311^{*}$ & $.282^{*}$ & $.451^{*}$ \\
\hline
\end{tabular}

Note: Coefficients being significantly different from each other at least at the .05 -level are marked with an asterisk. Please note that the significance test takes the sample size into account. We also tested the differences using the absolute difference between the correlations due to the reverse coding of the switching variable: $\Delta \mathrm{r}=\left|\mathrm{r}_{\text {present }}\right|-\left|\mathrm{r}_{\text {meta }}\right|$. 
TABLE 6

RESULTS OF HYPOTHESES TESTING (THREE-DIMENSIONAL SWITCHING COSTS TYPOLOGY)

\begin{tabular}{|c|c|c|c|c|c|c|}
\hline Construct & & Construct & $\mathbf{B}$ & t-value & Hyp. & Result \\
\hline \multirow{5}{*}{$\begin{array}{l}\text { Switching } \\
\text { Behavior } \\
\left(\mathrm{R}^{2}=.085\right)\end{array}$} & $\leftarrow$ & Procedural switching costs & -.137 & 1.573 & H1a & Rejected \\
\hline & & & & & & \\
\hline & $\leftarrow$ & Financial switching costs & -.062 & .665 & $\mathrm{H} 1 \mathrm{~b}$ & Rejected \\
\hline & $\leftarrow$ & Relational switching costs & -.165 & 2.072 & $\mathrm{H} 1 \mathrm{c}$ & Confirmed \\
\hline & $\leftarrow$ & Customer satisfaction & -.033 & .441 & & \\
\hline \multirow{4}{*}{$\begin{array}{l}\text { Share of } \\
\text { Wallet } \\
\left(\mathrm{R}^{2}=.230\right)\end{array}$} & $\leftarrow$ & Procedural switching costs & .141 & 1.761 & $\mathrm{H} 2 \mathrm{a}$ & Confirmed \\
\hline & $\leftarrow$ & Financial switching costs & .041 & .471 & $\mathrm{H} 2 \mathrm{~b}$ & Rejected \\
\hline & $\leftarrow$ & Relational switching costs & .176 & 2.405 & $\mathrm{H} 2 \mathrm{c}$ & Confirmed \\
\hline & $\leftarrow$ & Customer satisfaction & .337 & 4.890 & & \\
\hline \multirow{4}{*}{$\begin{array}{l}\text { Cross-Buying Behavior } \\
\text { (Products) } \\
\left(\mathrm{R}^{2}=.143\right)\end{array}$} & $\leftarrow$ & Procedural switching costs & .088 & 1.043 & $\mathrm{H} 3 \mathrm{a}$ & Rejected \\
\hline & $\leftarrow$ & Financial switching costs & .199 & 2.217 & $\mathrm{H} 3 \mathrm{~b}$ & Confirmed \\
\hline & $\leftarrow$ & Relational switching costs & .168 & 2.179 & $\mathrm{H} 3 \mathrm{c}$ & Confirmed \\
\hline & $\leftarrow$ & Customer satisfaction & .051 & .485 & & \\
\hline \multirow{4}{*}{$\begin{array}{l}\text { Cross-Buying Behavior } \\
\text { (Services) } \\
\left(\mathrm{R}^{2}=.253\right)\end{array}$} & $\leftarrow$ & Procedural switching costs & .067 & .820 & $\mathrm{H} 4 \mathrm{a}$ & Rejected \\
\hline & $\leftarrow$ & Financial switching costs & .208 & 2.368 & $\mathrm{H} 4 \mathrm{~b}$ & Confirmed \\
\hline & $\leftarrow$ & Relational switching costs & .330 & 4.461 & $\mathrm{H} 4 \mathrm{c}$ & Confirmed \\
\hline & $\leftarrow$ & Customer satisfaction & .035 & .515 & & \\
\hline
\end{tabular}

NOTE: Coefficients that are significant at the .05 or lower level (one-tailed) are in bold. 